\title{
Climate mitigation in the Mediterranean Europe: An assessment of regional and city-level plans
}

\author{
Monica Salvia $^{\text {a,* }}$, Marta Olazabal $^{\mathrm{b}}$, Paris A. Fokaides ${ }^{\mathrm{c}}$, Léa Tardieu ${ }^{\mathrm{d}}$, Sofia G. Simoes ${ }^{\mathrm{e}}$, \\ Davide Geneletti $^{\mathrm{f}}$, Sonia De Gregorio Hurtado ${ }^{g}$, Vincent Viguié ${ }^{\mathrm{h}}$, Niki-Artemis Spyridaki ${ }^{\mathrm{i}}$, \\ Filomena Pietrapertosa ${ }^{a}$, Byron I. Ioannou ${ }^{c}$, Marko Matosović ${ }^{j}$, Alexandros Flamos ${ }^{i}$, \\ Mario V. Balzan ${ }^{\mathrm{k}}$, Efren Feliu ${ }^{1}$, Klavdija Rižnar ${ }^{\mathrm{m}}$, Nataša Belšak Šel ${ }^{\mathrm{m}}$, Oliver Heidrich ${ }^{\mathrm{n}}$, \\ Diana Reckien ${ }^{\circ}$ \\ ${ }^{a}$ Institute of Methodologies for Environmental Analysis, National Research Council of Italy, C.da S. Loja, 85050, Tito Scalo, PZ, Italy \\ ${ }^{\mathrm{b}}$ Basque Centre for Climate Change (BC3), Parque Científico UPV/EHU, Barrio Sarriena, s/n, 48940, Leioa, Spain \\ ${ }^{\mathrm{c}}$ School of Engineering, Frederick University, 7, Frederickou Str., 1036, Nicosia, Cyprus \\ d TETIS, INRAE, AgroParisTech, Cirad, CNRS, Univ Montpellier, F-34093, Montpellier, France \\ e The National Energy Laboratory of Portugal (LNEG), Unit on Resource Economics, Estrada da Portela, Bairro do Zambujal Ap 7586, 2720-999, Amadora, Portugal \\ ${ }^{\mathrm{f}}$ Department of Civil, Environmental and Mechanical Engineering, University of Trento, Via Mesiano 77, 38123, Trento, Italy \\ ${ }^{g}$ School of Architecture, Department of Urban and Spatial Planning, Universidad Politécnica de Madrid, Avenida de Juan de Herrera, 4, 28040, Madrid, Spain \\ ${ }^{\mathrm{h}}$ Centre International de Recherche sur l'Environnement et le Développement (CIRED), 45bis, Av de la Belle Gabrielle, F-94736, Nogent-sur-Marne, France \\ ${ }^{i}$ Department of Industrial Management \& Technology, University of Piraeus (UNIPI), 80, Karaoli \& Dimitriou street, 18534, Piraeus, Greece \\ ${ }^{j}$ PwC Savjetovanje, Heinzelova 70, 10000, Zagreb, Croatia \\ ${ }^{\mathrm{k}}$ Institute of Applied Sciences, Malta College of Arts, Science and Technology, Paola, PLA9032, Malta \\ ${ }^{1}$ TECNALIA, Basque Research and Technology Alliance (BRTA), Parque Tecnológico de Bizkaia, Astondo Bidea, edificio 700c/ Geldo, 48160, Derio, Spain \\ ${ }^{\mathrm{m}}$ Scientific Research Centre Bistra Ptuj, Slovenski trg 6, 2250, Ptuj, Slovenia \\ ${ }^{\mathrm{n}}$ School of Engineering, Tyndall Centre for Climate Change Research, Newcastle University, Newcastle upon Tyne, NE1 7RU, United Kingdom \\ ${ }^{\circ}$ Faculty of Geo-Information Science and Earth Observation, University of Twente, PO Box 217, 7500 AE, Enschede, Netherlands
}

\section{A R T I C L E I N F O}

\section{Keywords:}

Climate mitigation

Mediterranean Europe

Local mitigation planning

City

Region

\begin{abstract}
A B S T R A C T
In Europe, regions in the Mediterranean area share common characteristics in terms of high sensitivity to climate change impacts. Does this translate into specificities regarding climate action that could arise from these Mediterranean characteristics? This paper sheds light on regional and local climate mitigation actions of the Mediterranean Europe, focusing on the plans to reduce greenhouse gases emissions in a representative sample of 51 regions and 73 cities across 9 Mediterranean countries (Croatia, Cyprus, France, Greece, Italy, Malta, Portugal, Slovenia, Spain). The study investigates: (i) the availability of local and regional mitigation plans, (ii) their goals in term of greenhouse gas emissions reduction targets on the short and medium-long term, and (iii) the impact of transnational climate networks on such local and regional climate mitigation planning. Results of this study indicate an uneven and fragmented planning, that shows a Mediterranean West-East divide, and a link with population size. However, overall, both regional and city action seem insufficiently ambitious with regards to meeting the Paris Agreement, at least at city level. While national frameworks are currently weak in influencing regional and local actions, transnational networks seem to be engaging factors for commitment (at city level) and ambitiousness (at regional level). The uneven and fragmented progress revealed by this study, does not align with the characteristics shared by investigated regions and cities in terms of environmental, socio-political, climatic and economic conditions. The results support the call of a common green deal at the Mediterranean level to further address specific Mediterranean challenges and related needs. This will allow to capitalise on
\end{abstract}

\footnotetext{
* Corresponding author.

E-mail addresses: monica.salvia@imaa.cnr.it (M. Salvia), marta.olazabal@bc3research.org (M. Olazabal), eng.fp@frederick.ac.cy (P.A. Fokaides), lea.tardieu@

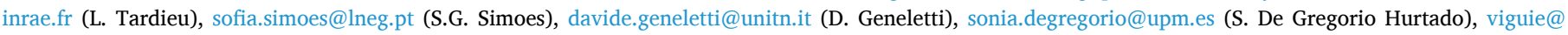

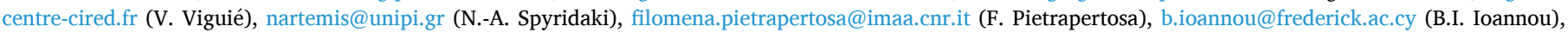

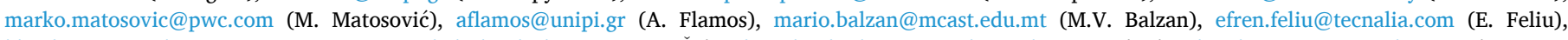
klavdija.riznar@bistra.si (K. Rižnar), natasa.belsak.sel@bistra.si (N.B. Šel), oliver.heidrich@newcastle.ac.uk (O. Heidrich), d.reckien@utwente.nl (D. Reckien).
} 
available resources, generate local-specific knowledge, build capacities, and support Mediterranean regions and cities in preparing the next generation of more ambitious mitigation plans.

\section{Introduction}

The Paris Agreement at COP21 made it imperative to fight climate change and to intensify actions and investments for a sustainable low carbon future. The Mediterranean Europe (ME) is particularly sensitive to climate change (Loizidou et al., 2016) with extremely different and challenging conditions regarding climate, environment (FAO, 2018), biodiversity, socio-political and demographic aspects in relation to the rest of Europe (UNEP/MAP, 2016). The Mediterranean region has a specific bioclimate with typical forest, fauna and flora. The region is characterised by important pressures on the environment while being highly vulnerable to climate change. For example, Mediterranean countries face high population growth, high tourism, wide urbanization and significant strain on coastal areas. The Mediterranean region is identified as one of the most vulnerable regions to climate change and defined as a major "hotspot" based on the results of global climate change projections (Giorgi and Lionello, 2008). In addition, intense environmental effects including rapid changes in the water cycle due to increased evaporation and lower precipitation, decrease in soil water storage capacity accelerating desertification as well as extinction of the most climate-sensitive or least mobile species and colonization by new species. Over the last decade the impacts of climate change have for instance particularly affected the ME region (Giorgi and Lionello, 2008), raising concerns about how countries, regions and cities in these areas can cope with the consequences of climate change while contributing to mitigating GHG emissions (Cramer et al., 2020).

The categorization of policies across regions but also the exchange of experience and knowledge between different regions, can lead to improved policy making and effectiveness (Karhinen et al., 2021). Countries in Mediterranean Europe share important similarities in terms of climate and socio-cultural elements, thus Mediterranean themed networks and policies are justified. Current initiatives, such as the call for a new climate pact made at the Euro-Mediterranean Regional and Local Assembly held in Barcelona in January 2020 (ARLEM, 2020), are pioneers and evidence of the policy interest in this topic. To advance the understanding it is important to assess to what extent there are commonalities in regional and local climate planning across the Euro-Mediterranean area. Hence, the analysis of climate and sustainability policies planned and implemented across Mediterranean cities, can inform future strategies. Such an analysis is even more important, as almost one in four citizens of the European Union do reside in the Mediterranean basin.

This paper explores the case for Mediterranean cities by analysing specifically how cities and regions are currently planning to address climate mitigation in ME (Olazabal et al., 2014). By analysing the plans to reduce greenhouse emissions, and under the hypothesis that ME regions and cities face similar challenges in mitigation policies, this study aims to generate knowledge around GHG reduction targets, needs and leadership in the Mediterranean area, to expand public policy of climate change planning and to explore a case for cross-border comparison and cooperation in $\mathrm{ME}$ in the field of climate change mitigation in the context of the European Green Deal (European Commission, 2019). This study explores cases for cross-border comparison and cooperation in ME in the field of climate change mitigation in the context of the European Green Deal (European Commission, 2019). Mitigation plans in 73 cities and their corresponding 51 regions - located in 9 countries of the ME, as defined by the Interreg MED Programme (Interreg MED Programme, 2020) - are retrieved and analysed.

This study presents a comprehensive assessment of the mitigation plans of Mediterranean Europe. The innovation beyond the state of the art of this study lies in the fact that this is the first comprehensive documentation and analysis of mitigation plans in the EuroMediterranean area and draws specific and general conclusions regarding the strategies implemented by the cities and regions and their ambition to combat climate change. This study informs future policy making initiatives and supports sustainable management practices of the urban environment in the Mediterranean basin.

\section{Literature review}

The magnitude of climate change impacts on the Mediterranean Basin has been observed to exceed the average trend at the global level (Cramer et al., 2018). For example, higher frequency and intensity of droughts and heat waves have been already recorded, causing increased impacts such as heat stress (Polydoros et al., 2018), water scarcity and associated environmental problems in cities, such as degraded air quality (Lelieveld et al., 2012). Climate change-induced coastal hazard (Nicholls and Hoozemans, 1996) and river flooding (Ribas et al., 2020; Vinet et al., 2019) pose additional high risks, according to the vulnerability of the ME from both an ecological and a socio-economic perspective. Climate risks in the ME area are significant (Billé et al., 2013), due to both the magnitude and frequency of the hazards involved, the vulnerability of these areas and the limited adaptive capacity. The latter is due to the lack of financial tools, a great socio-economic diversity across population groups and poor or inadequate governance and conditions of urban infrastructures and settlements (Cramer et al., 2018).

This calls for a distinction of the ME as regards climate governance in relation to the rest of Europe. For example, sectorial analyses such as those focused on health (Linares et al., 2020) or water (Iglesias et al., 2007) emphasised the need for enhanced cross-border collaboration, due to the fact that these risks require a multi-stakeholder and multi-institutional approach. The case for a Mediterranean distinction, is also subject to the context of energy efficiency and carbon neutrality in cities, since many challenges, such as low-income housing, urbanization and behaviours are common in these areas (Baabou et al., 2017), being crucial factors for both climate vulnerability and carbon footprint. In line with this, a new climate pact was called at the Euro-Mediterranean Regional and Local Assembly held in Barcelona in January 2020, to strengthen cooperation and facilitate new financial tools to accelerate the efforts to adapt and build resilience by delivering climate action across the Mediterranean region (European Committee of the Regions, 2020). However, the case for such collaboration in the field of climate mitigation action in the Mediterranean area, has not been properly addressed yet. Previous research in this field focused on understanding the North-South divide in Europe regarding emission reduction targets (Reckien et al., 2014) and cross-national policy (Heidrich et al., 2016), the level of national climate leadership in Mediterranean countries (De Gregorio Hurtado et al., 2014), and the influence of transnational networks on local climate plans (LCPs) (Reckien et al., 2015). However, to the best of the authors knowledge, there are no systematic assessments of the similarities and differences of climate actions undertaken at different governance levels across Mediterranean Europe.

Science and engineering need to be concerned in the direction of a rapid response to climate change (Schneider and Sanguinetti, 2021). Multidimensional climate management is the key to the commitment of sub-national levels to achieve their respective national and international goals. An efficient cooperation among the various levels of government should be enhanced in order to better encourage and support local ingenuity (Pietrapertosa et al., 2021). When it comes to pursuing sustainable growth strategies, islands experience particular problems. 
Legislation knowledge gaps persist, such as an absence of benchmarks, limited dissemination of information presented, and inadequate convergence across policy realms.

Local Climate Action Plans address major challenges of the urban built environment (Reckien et al., 2014). The environmental aspects extend beyond the promotion of alternative energy resources and cover multiple areas of sustainable development. Given that water is the main element restraining ecological performance, encouraging sustainable land management activities is a way to preserve the Mediterranean Basin hydrological cycle regulation in order to implement sustainable plans and achieve healhier and diversified habitat (Ruiz et al., 2020). Extensive and accelerated urbanization causes various challenges; among them is air quality that remains a concern in European cities, with different urban centers consistently breaching the European Union Air Quality Standards for $\mathrm{PM}_{2.5}$ and $\mathrm{NO}_{2}$ concentrations (Wang et al., 2020). Sustainable urban mobility initiatives are an effective regulatory tool for improving the urban transportation system and standard of living (Pisoni et al., 2019). Green infrastructure (GI) reinvigorates trees and soil, retains hydro-ecological cycles disrupted by urban development, and regulates wastewater naturally on-site, providing various sustainability advantages (Tiwary et al., 2016). The adoption of GI in Mediterranean Europe did not evolve at the same rate as in other European regions. Social recognition can be developed through the understanding of GI via education and awareness and removing conceptual obstacles as a consequence (Dhakal and Chevalier, 2017). The latest data indicate that European countries are still not established to fulfill the Paris Agreement, a target of which was net-zero emissions about the year 2050. On the contrary, immediate actions are needed to achieve the stated average mitigation target of GHG reduction by $47 \%$ across European cities (Salvia et al., 2021). Further research should be directed toward elucidating the role of data and mechanization in supporting the mutual wisdom of smart cities for the benefit of urban sustainability (Palumbo et al., 2021). Smart cities are the leading movement towards a tenacious ecosystem. In the fields of resource efficiency, intelligent mobility, intelligent living, and sophisticated environment, smart buildings are more likely to enhance their smartness through the use of advanced planning (Apanaviciene et al., 2020).

\section{Materials and methods}

\subsection{Sample of $M E$ regions and cities}

This work focused on 9 ME countries: France, Italy, Spain, Greece, Portugal, Croatia, Slovenia, Cyprus, Malta. In order to identify the sample of regions and cities, the boundaries of the study area were defined by combining information on the European countries and regions within the Interreg MED cooperation area 2014-2020 (Interreg MED Programme, 2020) with cities in those regions which are included in the Urban Audit (UA) database (Eurostat, 2020a). The term "regions" in this work corresponds to NUTS level 2 regions, as reported in Table 1 together with the respective cities. The UA database provides a balanced and representative sample of cities in terms of population, geographical distribution and city size. Fig. 1 shows the sampled regions and cities.

The Mediterranean sample includes peculiarities for smaller regions, e.g. in Cyprus and Malta the NUTS level 2 region coincides with the country area (European Parliament and of the Council, 2013), thus it does not represent a separate administrative entity. The same happens for Croatia where the NUTS level 2 regions (Adriatic Croatia and Continental Croatia) are statistical constructs, which will probably change in the near future (Ministry of Regional Development and EU Funds, 2020). Regions in Slovenia (Eastern Slovenia and Western Slovenia) do not represent real administrative entities for regional planning, but are responsible for the implementation of the EU Cohesion Policy programmes (Cohesify, 2017).

The sample of 51 regions (at Eurostat NUTS level 2) covers a total population of 124.4 million inhabitants in 2019 (Eurostat, 2020b). Italy
Table 1

Overview of the Countries, Regions and Cities included in this study. In italics the NUTS level 2 regions, which do not correspond to administrative regional entities, are highlighted.

\begin{tabular}{|c|c|c|}
\hline Countries & Regions (No.) & Cities (No.) \\
\hline Croatia & $\begin{array}{l}\text { Adriatic Croatia, Continental } \\
\text { Croatia (2) }\end{array}$ & $\begin{array}{l}\text { Zagreb, Rijeka, Slavonski, Brod, } \\
\text { Osijek, Split (5) }\end{array}$ \\
\hline Cyprus & Cyprus (1) & Lefkosia (1) \\
\hline France & $\begin{array}{l}\text { Corse, Languedoc-Roussillon, } \\
\text { Midi-Pyrénées (now Occitanie), } \\
\text { Provence Alpes Côte d'Azur, } \\
\text { Rhône-Alpes (now Auvergne- } \\
\text { Rhône-Alpes) (5) }\end{array}$ & $\begin{array}{l}\text { Marseille, Lyon, Toulouse, Nice, } \\
\text { Montpellier, Saint-Étienne, } \\
\text { Grenoble, Ajaccio, Toulon, Aix- } \\
\text { en-Provence (10) }\end{array}$ \\
\hline Greece & $\begin{array}{l}\text { Eastern Macedonia, Thrace, } \\
\text { Central Macedonia, West } \\
\text { Macedonia, Epirus, Thessaly, } \\
\text { Ionian Island, Western Greece, } \\
\text { Central Greece, Peloponnese, } \\
\text { Attica, North Aegean, South } \\
\text { Aegean, Crete (13) }\end{array}$ & $\begin{array}{l}\text { Athina, Thessaloniki, Pátra, } \\
\text { Iraklio, Larisa, Volos, Ioannina, } \\
\text { Kavala, Kalamata (9) }\end{array}$ \\
\hline Italy & $\begin{array}{l}\text { Abruzzo, Apulia, Basilicata, } \\
\text { Calabria, Campania, Emilia- } \\
\text { Romagna, Friuli-Venezia Giulia, } \\
\text { Lazio, Liguria, Lombardy, } \\
\text { Marche, Molise, Piedmonte, } \\
\text { Sardinia, Sicily, Tuscany, Umbria, } \\
\text { Veneto (18) }\end{array}$ & $\begin{array}{l}\text { Roma, Milano, Napoli, Torino, } \\
\text { Palermo, Genova, Firenze, Bari, } \\
\text { Bologna, Catania, Venezia, } \\
\text { Verona, Cremona, Trieste, } \\
\text { Perugia, Ancona, l'Aquila, } \\
\text { Pescara, Campobasso, Caserta, } \\
\text { Taranto, Potenza, Catanzaro, } \\
\text { Reggio di Calabria, Sassari, } \\
\text { Cagliari, Padova, Brescia, } \\
\text { Modena, Foggia, Salerno (31) }\end{array}$ \\
\hline Malta & Malta (1) & Valletta, Gozo (2) \\
\hline Portugal & $\begin{array}{l}\text { Algarve, Alentejo, Lisboa e Vale } \\
\text { do Tejo (3) }\end{array}$ & Lisboa, Setúbal, Faro (3) \\
\hline Slovenia & $\begin{array}{l}\text { Eastern Slovenia, Western } \\
\text { Slovenia (2) }\end{array}$ & Ljubljana, Maribor (2) \\
\hline Spain & $\begin{array}{l}\text { Andalusia, Catalonia, Valencian } \\
\text { Community, Aragon, Balearic } \\
\text { Islands, Murcia (6) }\end{array}$ & $\begin{array}{l}\text { Barcelona, Valencia, Sevilla, } \\
\text { Zaragoza, Málaga, Murcia, Palma } \\
\text { de Mallorca, Córdoba, Alicante, } \\
\text { L’Hospitalet de Llobregat (10) }\end{array}$ \\
\hline
\end{tabular}

(48\%), Spain (20\%), and Greece (9\%) are the biggest contributors in terms of population. The sample of 73 cities covers a population of 27, 109,575 inhabitants, which varies from 32,723 inhabitants of Gozo (Malta) to 2,872,800 inhabitants of Rome (Italy), with an average value of 371,364 inhabitants across the entire city sample. Overall, the sample covers highly different region and city realities in terms of population size providing a good input for the study.

\subsection{Methodological approach for the collection and analysis of planning documents}

The methodological approach was based on four key research steps as presented in Fig. 2 and described below.

Relevant climate planning documents were first searched on the web, both using the official language of the country (to get access to national and regional sources) and English. Then the search was extended to data repositories provided by the transnational climate alliances listed in Table 2. At the regional level, the investigation focused on plans with a clear reference to climate change and mitigation in the title. In case these were not available, other types of planning documents were collected, including regional energy plans or strategic development plans with region-wide targets on the reduction of greenhouse gases (GHG) and $\mathrm{CO}_{2}$ emissions.

A repository of all the analysed municipal and regional plans (M-LCP and R-LCP), accessible through their web sources, is provided as Supplementary Materials. In particular, local climate mitigation plans (MLCP) for UA cities were extracted from a previous study by these authors (Salvia et al., 2021) and the related dataset ([dataset] Salvia et al., 2020). The M-LCP for these cities were catalogued and analysed following the methodology described by the authors in (Reckien et al, 2018, 2019), which distinguishes among the following plans and 


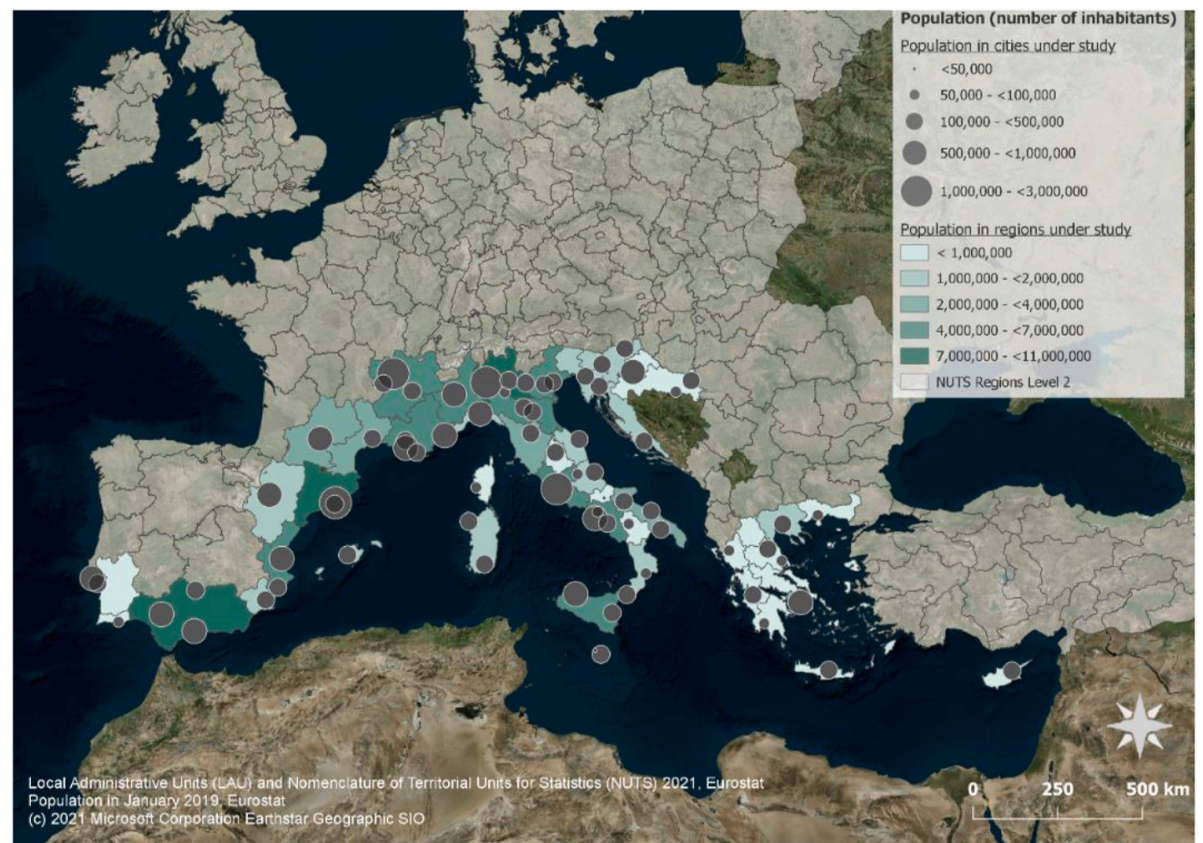

Fig. 1. The selected regions and cities (resident population expressed in number of inhabitants).

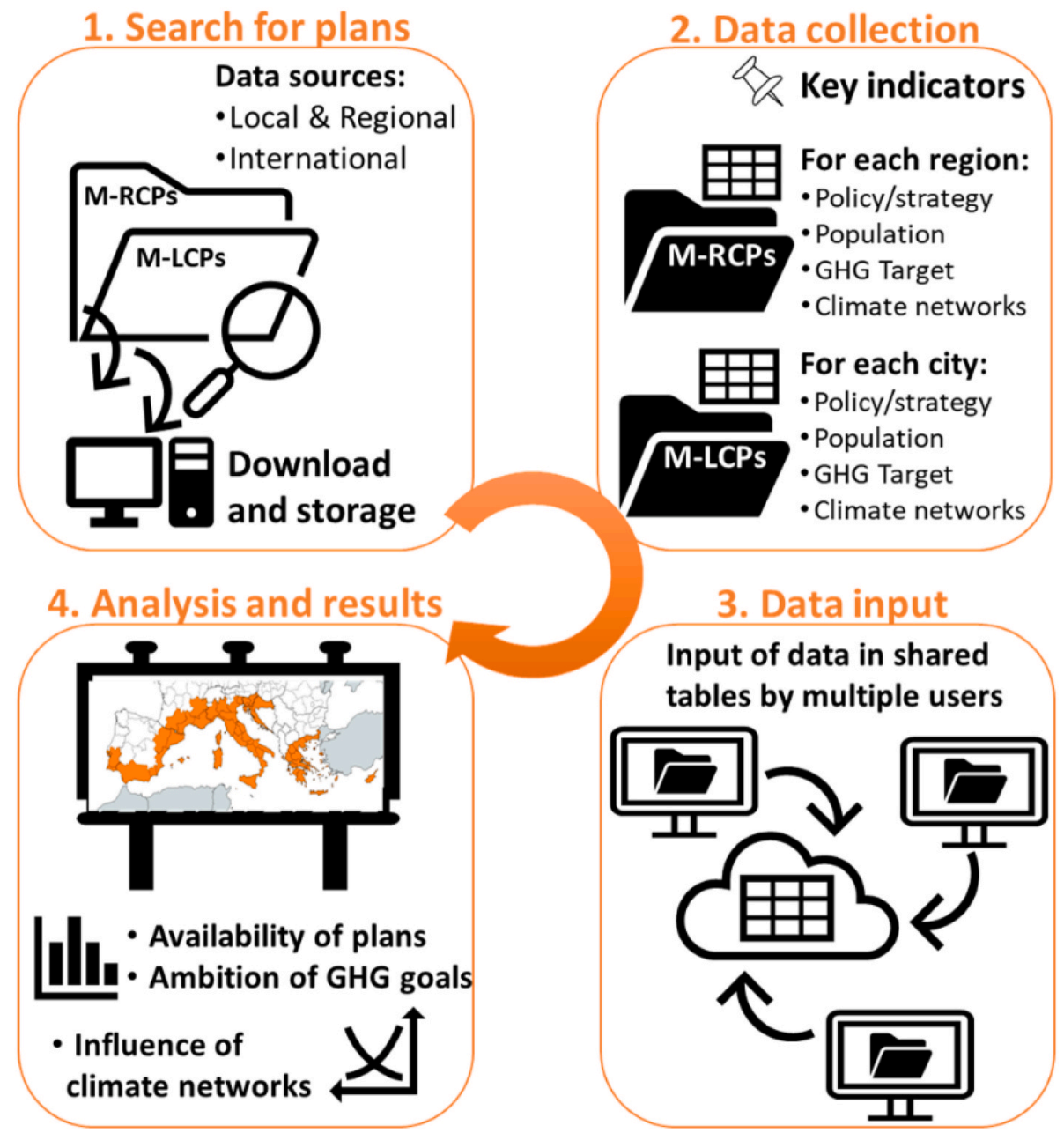

Fig. 2. Flowchart of the research method utilized in this study (M-LCP: Local Climate Mitigation Plans; M-RCP: Regional Climate Mitigation Plans). 
Table 2

National mitigation frameworks.

\begin{tabular}{|c|c|c|c|}
\hline Country & $\begin{array}{l}\text { Name of the policy (strategy/action plan/other) - Year of } \\
\text { adoption }\end{array}$ & GHG goal & $\begin{array}{l}\text { National obligation to develop regional and/ } \\
\text { or urban mitigation plan }\end{array}$ \\
\hline \multirow[t]{3}{*}{$\begin{array}{r}\text { Croatia } \\
\text { (HR) }\end{array}$} & $\begin{array}{l}\text { National Energy and Climate Plan (NECP) - adopted in } \\
2019\end{array}$ & $\begin{array}{l}\text { NECP sets the goal of achieving } 43 \% \text { GHG reduction in } \\
\text { the ETS sector by } 2030 \text { and } 7 \% \text { for non-ETS sectors, } \\
\text { compared to } 2005 \text {. }\end{array}$ & \multirow[t]{3}{*}{ No } \\
\hline & $\begin{array}{l}\text { Low Carbon Development Strategy (LCDS) until } 2030 \\
\text { with outlook until } 2050 \text { - adopted in } 2021\end{array}$ & $\begin{array}{l}\text { LCDS sets the goal of achieving } 33.5 \% \text { GHG reduction in } \\
2030 \text { compared to } 1990 \text {. }\end{array}$ & \\
\hline & $\begin{array}{l}\text { National Energy Strategy (NES) until } 2030 \text { with outlook } \\
\text { until } 2050 \text { - adopted in } 2020\end{array}$ & $\begin{array}{l}\text { NES sets the goal of achieving } 35.4 \% \text { GHG reduction in } \\
2030 \text { compared to } 1990 \text {. }\end{array}$ & \\
\hline $\begin{array}{c}\text { Cyprus } \\
\text { (CY) }\end{array}$ & $\begin{array}{l}\text { Cyprus' Integrated National Energy and Climate Plan - } \\
\text { adopted in } 2020 \\
\text { Before CINEC, the NREAP was setting the objective of } \\
\text { reducing GHG by at least } 20 \% \text { in } 2020\end{array}$ & $\begin{array}{l}\text { Sets the goal of achieving } 24 \% \text { GHG reduction by } 2030 \text {. } \\
\text { Industry, Buildings' Carbon Neutrality by } 2050 \text {. }\end{array}$ & $\begin{array}{l}\text { Supportive reference to the Cyprus' } \\
\text { Government Initiative for a Regional Action } \\
\text { Plan for the Eastern Mediterranean \& Middle } \\
\text { East Countries }\end{array}$ \\
\hline $\begin{array}{r}\text { France } \\
\text { (FR) }\end{array}$ & $\begin{array}{l}\text { Stratégie Nationale Bas-Carbone (SNBC) - adopted in } \\
\text { 2015, revised in 2018-2019 } \\
\text { Before the SNBC, the Grenelle II law was setting the } \\
\text { objective of reducing GHG by at least } 20 \% \text { in } 2020\end{array}$ & $\begin{array}{l}\text { Sets the goal of achieving carbon neutrality by } 2050 \\
\text { (divide at least by } 6 \text { carbon emissions by } 2050 \text { compared } \\
\text { to } 1990 \text { ) }\end{array}$ & Yes since the Grenelle II law of July 2010 \\
\hline $\begin{array}{c}\text { Greece } \\
(\text { EL) }\end{array}$ & $\begin{array}{l}\text { National Energy and Climate Plan (NECP) - adopted in } \\
2019 \\
\text { National Strategy for Adaptation to Climate Change } \\
\text { (NSACC) - adopted in } 2016\end{array}$ & $\begin{array}{l}\text { The Greek NECP has the goal of reducing GHG emissions } \\
\text { by at least } 56 \% \text { in } 2030 \text { compared to } 2005 \text {. } \\
\text { The Greek NSACC sets the general objectives, guidelines } \\
\text { and means of implementing an effective and } \\
\text { developmental strategy for adapting to climate change. }\end{array}$ & $\begin{array}{l}\text { Yes since the Law } 4414 / 2016 \text { (article 43) of } \\
2016 .\end{array}$ \\
\hline Italy (IT) & $\begin{array}{l}\text { National Energy and Climate Plan (NECP) - 2019 ( } \\
\text { Ministry of Economic Development et al., 2019) }\end{array}$ & $\begin{array}{l}\text { The NECP was drawn up in close collaboration with the } \\
\text { regions with the aim of reducing GHG emissions by at } \\
\text { least } 40 \% \text { in } 2030 \text { compared to } 1990 \text {. }\end{array}$ & No \\
\hline $\begin{array}{l}\text { Malta } \\
\text { (MT) }\end{array}$ & $\begin{array}{l}\text { Malta's } 2030 \text { National Energy and Climate Plan (NECP) - } \\
2019\end{array}$ & $\begin{array}{l}\text { By } 2030 \text { reduce GHG emissions by } 19 \% \text { below the } 2005 \\
\text { emissions }\end{array}$ & No \\
\hline \multirow[t]{2}{*}{$\begin{array}{l}\text { Portugal } \\
\text { (PT) }\end{array}$} & $\begin{array}{l}\text { National Energy and Climate Plan } 2030 \text { (PNEC2030) - } \\
2019\end{array}$ & $\begin{array}{l}\text { The PNEC } 2030 \text { does not include the regional/local } \\
\text { dimension and has the goal of reducing GHG emissions } \\
\text { by at least } 45-55 \% \text { in } 2030 \text { compared to } 2005 \text {. }\end{array}$ & \multirow[t]{2}{*}{ No } \\
\hline & $\begin{array}{l}\text { National Carbon Neutrality Roadmap (RNC2050) } \\
\text { (Portuguese Government, 2019) }\end{array}$ & $\begin{array}{l}\text { RNC } 2050 \text { sets the goal of achieving carbon neutrality for } \\
\text { the whole of the country by } 2050 \text {. The specific } \\
\text { contribution of cities and regions is not addressed. }\end{array}$ & \\
\hline \multirow[t]{2}{*}{$\begin{array}{l}\text { Slovenia } \\
\text { (SI) }\end{array}$} & $\begin{array}{l}\text { Comprehensive National Energy and Climate Plan of the } \\
\text { Republic of Slovenia - NEPN ("Celoviti nacionalni } \\
\text { energetski in podnebni načrt Republike Slovenije), } \\
\text { adopted by Government of the Republic of Slovenia } \\
\text { (February } 28,2020 \text { ) }\end{array}$ & $\begin{array}{l}\text { NEPN is planned for the period up to } 2030 \text { (with a view to } \\
2040 \text { ); } \\
\text { By } 2030 \text {, GHGs will decrease by } 25 \% \text { compared to } 2017 \\
\text { and by } 36 \% \text { compared to } 2005 \text {. }\end{array}$ & \multirow[t]{2}{*}{ No } \\
\hline & $\begin{array}{l}\text { Resolution on the Long - Term Climate Strategy of } \\
\text { Slovenia until } 2050 \text { ("Resolucija o Dolgoročni podnebni } \\
\text { strategiji Slovenije do 2050"), adopted by Government of } \\
\text { the Republic of Slovenia (April 21, 2021) }\end{array}$ & $\begin{array}{l}\text { By } 2050 \text {, Slovenia will reduce greenhouse gas (GHG) } \\
\text { emissions by } 80-90 \% \text { compared to } 2005 \text { and improve } \\
\text { sinks, while accelerating the implementation of policies } \\
\text { to adapt to climate change and ensure the climate } \\
\text { security of the population. }\end{array}$ & \\
\hline Spain (ES) & $\begin{array}{l}\text { Integrated Energy and Climate Plan - Plan Nacional } \\
\text { Integrado de Energía y Clima (PNIEC) 2021-2030 - } \\
\text { Adopted in } 2020\end{array}$ & $\begin{array}{l}\text { PNIEC } 2030 \text { has the goal of reducing GHG emissions by } \\
23 \% \text { in } 2030 \text { compared to 1990, which implies reducing } \\
\text { current emissions by } 33 \% \text {. }\end{array}$ & No \\
\hline
\end{tabular}

documents:

(i) comprehensive plans, autonomously developed or nationally induced;

(ii) plans developed within transnational climate networks, mainly the Sustainable Energy and Climate Plans developed within the Covenant of Mayors for Climate and Energy;

(iii) planning documents that integrate mitigation policies;

(iv) sectoral plans (e.g. energy plans), provided that they include citywide targets.

The second step dealt with the content analysis of the collected MLCP and M-RCP on the basis of a common set of qualitative and quantitative indicators. For M-RCP, these included the name of the region, the country, the population, the name of the policy/strategy, the target type and scale, the target and the base year and a short target summary. Analogously, the data collected for M-LCP included the name of the city and its population, the name of the plan/strategy, the $\mathrm{GHG} / \mathrm{CO}_{2}$ emission target, the target and the base years, and the description of the carbon neutrality target (if available).

All this information was completed with data on the participation of regions and cities in the transnational climate alliances listed in Table 3. In particular, the main commitments of regions to address climate change were gathered from the Data Partnerships for the Non-State Actor Zone for Climate Action (NAZCA) global platform (United Nations Climate Change, 2020).

The diversity of languages spoken across the ME required language proficient analysts, who extracted data from the identified planning documents and reported it into shared cloud platform spreadsheets.

Making use of such data, the analysis was structured around three research themes:

(i) The availability of urban and regional mitigation plans,

(ii) The goals and strategies to reduce greenhouse gas emissions on the short and medium-long term (reported in these plans);

(iii) The impact of transnational climate networks on such local and regional climate mitigation planning. below.

These themes correspond to the three Sections of Chapter 4 (Results)

\subsection{Data analysis methodology}

To explore how cities and regions are currently planning to address climate mitigation in the ME, simple descriptive statistics and graphical analysis was applied to the key research themes and variables 
mentioned above. The analysis was inspired by the approach used in (Reckien et al., 2018).

Accordinlgy a database was built, detailing, for each one of the 61 cities and 51 regions the:

- Existence of a Mitigation climate plan;

- City/region population;

- GHG mitigation targets, including: target year (classified as short term up to 2030 inclusive and long term), base-year, target value (in $\%$ mitigation) and indication if ambition is to achieve carbon neutrality;

- influence of international networks in R-LCP development, such as Covenant of Mayors, including existence of SEAP and/or SECAP plans.

The plans were analysed individually for each city and region and the availability of plans were plotted against city/region population size. Next the ambition of the local mitigation plans was analysed and graphically illustrated with respect to their GHG emission reduction targets as well as their timeline (i.e. base and target year). Finally, to analyse the influence of international networks, the significance of each network was calculated as a simple percentage of "member" cities/regions of each network over total cities/regions in the sample.

Table 3

Main transnational climate networks among European regions and cities considered in this study.

\begin{tabular}{|c|c|c|}
\hline Network & Main aim & Website \\
\hline \multicolumn{3}{|l|}{ Regions } \\
\hline Under2 Coalition & $\begin{array}{l}\text { It "is a global community of state } \\
\text { and regional governments" which } \\
\text { "include signatories to the Under } 2 \\
\text { Memorandum of Understanding } \\
\text { (MoU) as well as national endorsers } \\
\text { and other supporters". }\end{array}$ & $\begin{array}{l}\text { https://www. } \\
\text { under2coalition.org/ }\end{array}$ \\
\hline The Climate Group & $\begin{array}{l}\text { It aims "to accelerate climate } \\
\text { action by bringing together } \\
\text { powerful networks of business and } \\
\text { governments that shift global } \\
\text { markets and policies" }\end{array}$ & $\begin{array}{l}\text { https://www.th } \\
\text { eclimategroup.org/ }\end{array}$ \\
\hline Regions4 & $\begin{array}{l}\text { It claims to be "the global voice of } \\
\text { regional governments (states, } \\
\text { regions and provinces)" and } \\
\text { represent them "in climate fora, } \\
\text { primarily the UNFCCC } \\
\text { Conferences." }\end{array}$ & $\begin{array}{l}\text { https://www.regi } \\
\text { ons4.org/ }\end{array}$ \\
\hline \multicolumn{3}{|l|}{ Cities } \\
\hline $\begin{array}{l}\text { Covenant of Mayors } \\
\text { for Climate and } \\
\text { Energy (CoM) }\end{array}$ & $\begin{array}{l}\text { It "is the world's largest movement } \\
\text { for local climate and energy } \\
\text { actions". "Signatory cities pledge } \\
\text { action to support implementation } \\
\text { of the EU } 40 \% \text { greenhouse gas- } \\
\text { reduction target by } 2030 \text { and the } \\
\text { adoption of a joint approach to } \\
\text { tackling mitigation and adaptation } \\
\text { to climate change." }\end{array}$ & $\begin{array}{l}\text { https://www. } \\
\text { eumayors.eu/en/ }\end{array}$ \\
\hline C40 Cities (C40) & $\begin{array}{l}\text { "C40 is a network of the world's } \\
\text { megacities committed to } \\
\text { addressing climate change. C40 } \\
\text { supports cities to collaborate } \\
\text { effectively, share knowledge and } \\
\text { drive meaningful, measurable and } \\
\text { sustainable action on climate } \\
\text { change." }\end{array}$ & $\begin{array}{l}\text { https://www.c40. } \\
\text { org/ }\end{array}$ \\
\hline $\begin{array}{l}\text { Climate Alliance } \\
\text { (CA) }\end{array}$ & $\begin{array}{l}\text { The CA "city network stands for a } \\
\text { holistic approach to climate action, } \\
\text { linking concrete local solutions } \\
\text { with global responsibility". It "has } \\
\text { become a powerful community for } \\
\text { climate change mitigation and } \\
\text { adaptation". }\end{array}$ & $\begin{array}{l}\text { https://www.climat } \\
\text { ealliance.org/home. } \\
\text { html }\end{array}$ \\
\hline
\end{tabular}

\section{Results}

The availability and distribution of plans in the ME area (Section 4.1) is first presented, then the emission reduction targets for $\mathrm{GHG} / \mathrm{CO}_{2}$ set by the plans (Section 4.2) and finally the participation of the sampled regions and cities in transnational climate networks (Section 4.3).

\subsection{Plans distribution}

M-RCP were found in 15 out of the 51 analysed Mediterranean regions (29.4\%). The French and Spanish regions prove to be the most active in terms of climate mitigation planning. This is due to the fact that, in France, Regional Climate Air Energy Plans (SRCAE - Schéma Régional Climat Air Énergie) are compulsory since the Grenelle II Law while in Spain, which is a country structured around Autonomous Communities, all regions have a dedicated M-RCP. In Italy and Greece, the percentage of regions with a mitigation plan drops to 5.6\% (Emilia Romagna, one out of the 18 analysed regions) and $7.7 \%$ (Attica), respectively. Cyprus and Malta set their GHG emissions target in their National Energy and Climate Plans (NECPs) for the period 2021-2030, here also representing the regions. The other regions in the studied Mediterranean countries have no regional mitigation plans.

By discarding regions in France and Spain where the distribution of competences or regulatory structures has promoted regional mitigation planning, the results show that regions with larger population are more likely to have developed a regional mitigation plan (Fig. 3). For instance, in the sample, there are 18 regions with a population of less than 750,000 inhabitants, but only 2 of them have a plan. In contrast, half of the 16 regions with populations over 3 million have one.

Regarding planning at city-level, M-LCPs were found in 61 out of the 73 cities (83.6\% of the sample) in the ME region. Following the classification of LCP conceived and tested in (Reckien et al., 2018), the results show that $75.4 \%$ of the available M-LCPs (46 out of 61 ) were developed in the framework of commitments such as the Covenant of Mayors for Climate and Energy (CoM) and are mainly Sustainable Energy Action Plans (SEAP) with 20-20-20 objectives. From these, only few cities (5 out of 46: Zagreb, Ioannina, Lisbon, Sevilla, Valencia) have developed Sustainable Energy and Climate Plans (SECAP), which integrate in the same plan both climate change mitigation and adaptation objectives, referring to 2030 as target year. These findings underline the strong influence of the CoM in driving the development of M-LCPs in the Mediterranean area. Nevertheless, a very limited number of these signatories present long-term visions with higher ambition.

Comprehensive (i.e. autonomously developed) mitigation plans were found only for 12 cities in the sample: 2 Spanish cities (Murcia and Barcelona) and the 10 French cities. It should be noted that in France such plans (called PCAET - Plan Climat Air Energie/Climate Air Energy Plan) are mandatory by national law for cities with more than 20,000 inhabitants and need to be aligned with the regional plans (i.e. SRCAEs). Altogether 3 cities in the sample (Maribor, Ljubljana and Perugia) set mitigation targets within their municipal energy (and environmental) plan. Furthermore, 16 out of the 61 M-LCPs (including the 5 SECAPs) deal with both mitigation and adaptation in an integrated manner. Such results can suggest a weakness in developing independent M-LCPs and joint approaches for adaptation and mitigation across the majority of cities in the ME region. This in turn may mean that cities in the ME have an overriding need for support from the highest levels of government, as well as from other stakeholders.

Again, the availability of city mitigation plans presents a relation with the city population (Fig. 4). Additionally, results show that a population over 300,000 inhabitants seems to be a good indicator of availability of a M-LCP i.e. all cities in the sample with the population larger than 300,000 have urban mitigation plans.

It is worth noting that only one third of the cities with M-LCPs (i.e. 24 out of the 61 cities) belong to regions with M-RCPs. Regional planning therefore does not seem to be a determinant factor for local climate 


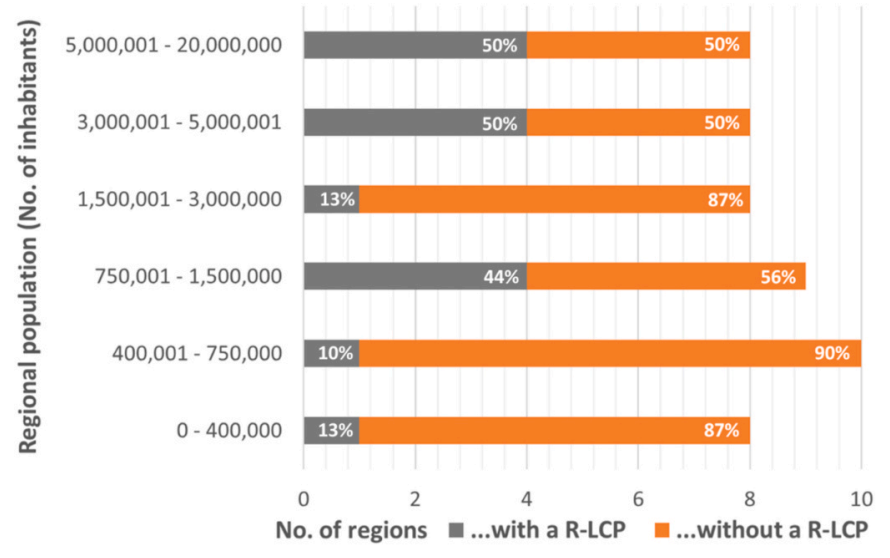

Fig. 3. Number of regions in the sample with and without plans, as a function of their population size.

action in the ME area. However, what holds to be true is that regional planning in the Mediterranean area is likely to be found in countries with climate mitigation regulatory structures at national level and with a distribution of competences that enhance climate regional action.

\subsection{Greenhouse gas (GHG) emission reduction targets}

Fig. 5 provides an overview of the GHG emission reduction targets, both for the short and the long term, reported in M-RCP.

Four regions (two in France, one in Greece and Italy) set a 20\% GHG reduction target by 2020 , whereas 5 Spanish regions set a target between $25 \%$ and $40 \%$. Cyprus and Malta, in their NECP, have set respectively a target of $24 \%$ and $19 \%$ by 2030 compared to 2005 values. Only one region, the Valencian Community, has a plan that does not set targets on GHG emissions reduction arguing that the reduction significantly depends on the action of the national government. Fig. 5 also highlights the strong influence of the regions' membership of the Under2 Memorandum of Understanding (Under2MoU) on long-term reduction which makes the long-term commitments on climate neutrality compulsory.

An overview of the ambition of the analysed M-LCPs is provided by Fig. 6. The figure shows that $39.3 \%$ of the M-LCPs aim to reduce GHG emissions by $20 \%, 34.4 \%$ of the M-LCPs target reductions between 21 and $30 \%, 18.0 \%$ of cities set a target between 31 and $40 \%$, and the remaining $8.2 \%$ considers more ambitious targets. However, more ambitious targets are always set for the long term, i.e. 2030, 2050. For example, Lisbon (Portugal) aims a $60 \%$ reduction of $\mathrm{CO}_{2}$ by 2030 compared to 2013 values, Sevilla (Spain) aims a $54 \%$ reduction of $\mathrm{CO}_{2} \mathrm{eq}$

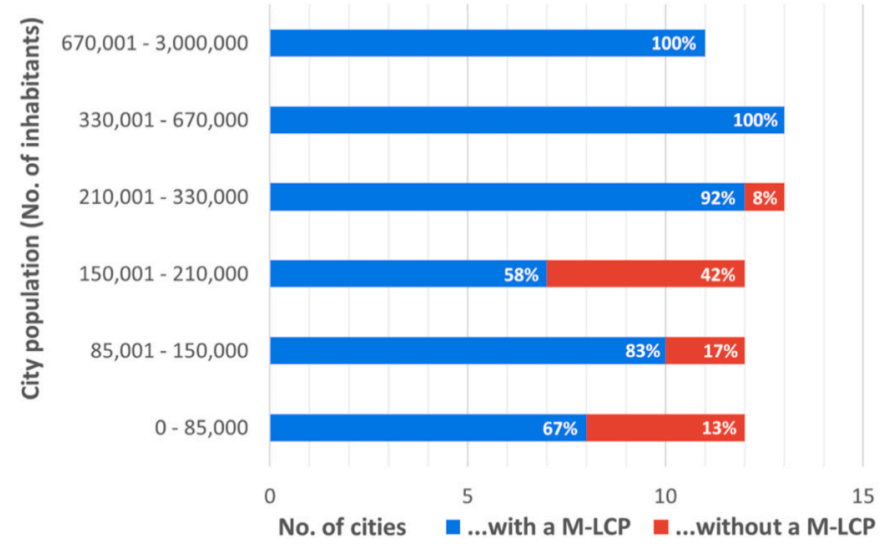

Fig. 4. Number of cities in the sample with and without plans, as a function of their population size. by 2030 compared to 2000 and Ajaccio (Italy) aims at $75 \%$ reduction by 2050 compared to 1990 . In addition to this, 5 cities (6.8\% of the overall city sample) strive for carbon neutrality by 2050: Venice and Milan (Italy) and Lisboa (Portugal) (the three of them are C40 cities), Padova (Italy) and Palma de Mallorca (Spain). The most ambitious activity seems to concentrate in countries such as Portugal, Spain and Italy.

\subsection{Integration in transnational climate networks}

In the sample, 12 out of 51 (23.5\%) regional governments (including Cyprus) are signatories of the Under2 Coalition (Under2 Coalition, 2020) with the Spanish region of Catalonia among the 12 founding signatories of this global community of state and regional governments committed to reducing emissions by $80-95 \%$, or limit to 2 metric tons $\mathrm{CO}_{2 \text { eq }}$ per capita, by 2050 or earlier. Moreover, $19.6 \%$ of the analysed regions are taking part in the Annual Disclosure initiative (The Climate Group, 2020), aimed at showcasing the level of ambition of states and regions in the field of climate mitigation and taking stock of the progresses made through measurement reporting and verification systems. Besides, 3 regions in the sample (5.9\%) have joined The Climate Group, and 2 regions (3.6\%) are involved in the Regions4 platform, dedicated to issues such as sustainability, biodiversity and climate change (Regions4, 2020).

With regard to the mitigation planning, $83.6 \%$ of cities in the sample are signatory of the Covenant of Mayors for Climate and Energy (CoM) (EU Covenant of Mayors, 2020). The CoM therefore plays a predominant role in the action of cities towards climate mitigation. Signatories of the C40 network (C40 cities, 2018) are 9.6\% (6 cities) of the total number of cities with M-LCP, and less than $3 \%$ are signatories of the Climate Alliance (Climate Alliance, 2020). The latter seems to have little influence on the Mediterranean cities, which is unlike in other parts of Europe (Salvia et al., 2021).

\section{Discussion}

The results point out that, even in the Mediterranean area, there is an uneven progress regarding mitigation planning, at least considering the UA sample of cities located in the regions of the Mediterranean coastal area of Europe. Earlier work pointed towards a North-South divide of local climate action planning in Europe (Reckien et al., 2014, 2018; Heidrich et al., 2016). The results show a potential West-East divide with regions and cities in Spain, Portugal, France and Italy having more local mitigation plans than cities in Croatia, Slovenia and Greece, for example.

Regionally, the availability of plans appears to be concentrated in countries with stronger governance and regulatory structures (illustrated in the Spanish and French cases). Notwithstanding, at national level all European Mediterranean countries submitted their integrated National Energy and Climate Plans (NECP) (European Commission, 2020a), the adoption of which was a legal requirement under the Regulation (EU) 2018/1999 on the Governance of the Energy Union and Climate Action. With the NECPs member countries have set national energy and climate objectives for 2030 (2050 in France) and key policy priorities for the development of specific measures. The regional and local mitigation plans analysed here have been mostly developed some years before the NECP adoption and, thus, respond mainly to the 2020 EU climate framework. Many of these plans are now under review or will be in the near future in order to be framed within national, transnational commitments (including the Paris agreement).

The study shows, that in countries where there is not a legal obligation to develop regional and local mitigation strategies, regions and cities are reactive to advance in this policy field (with the exception of France). This supports the case for a Mediterranean Green Deal. This finding further confirms the previous hypothesis on the lack of correspondence among European-led national climate and local climate policies across Europe (De Gregorio Hurtado, 2020). 


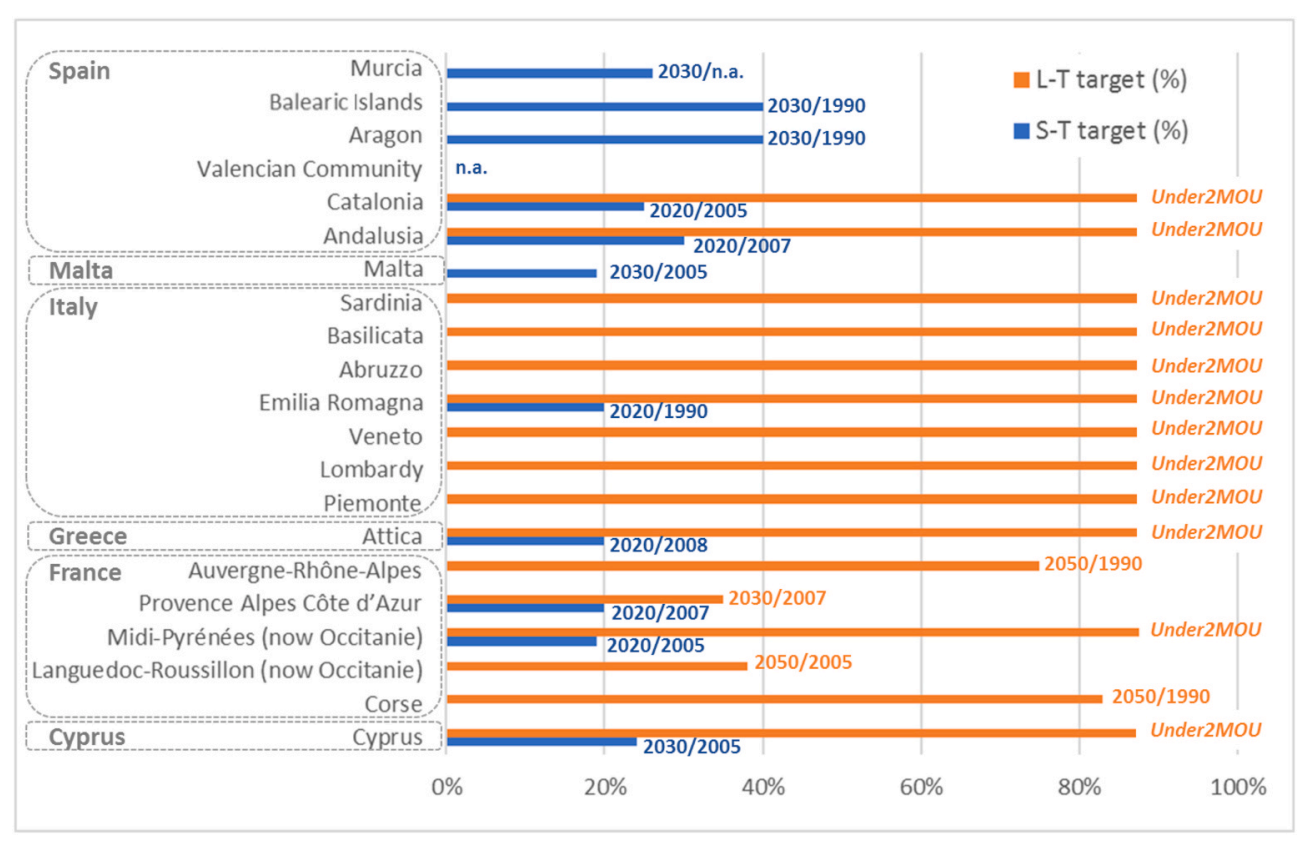

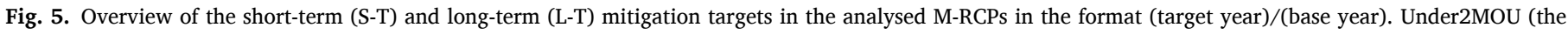

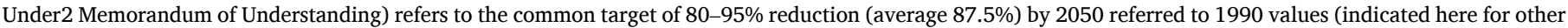
L-T targets as e.g. "2050/1990”).

Overall, regions in Southern Europe are still laggards in climate planning. An exception is provided by the Mediterranean regions at the forefront of the climate movement: the French regions, where the Schéma Régional Climat Air Énergie/Regional Climate Air Energy Plan are compulsory by law, and by the Spanish regions, in particular the region of Catalonia, that passed in 2017 its Climate Law with the specific objective of boosting coordination among governance levels. Although the development of regional climate plans is still limited, the influence of transnational climate networks, such as the Under2 Coalition, inspires regions to move towards climate neutrality in the long term (2050). However, this translational commitment framework, may also inhibit the establishment of more tangible short-term targets at regional level, as shown in the results of the analysis where the majority of regions with M-RCPs plan for the longer term.

The study has pointed out the great complexity as regards the administrative level at which climate initiatives are carried out, particularly in the Southern East Mediterranean Europe (i.e. Croatia and Slovenia) where "regional" initiatives often do not correspond to any administrative or statistical regions/borders, but are more connected with historical connections among municipalities, common problems, socio-economic situation, or simply geographical proximity. Furthermore, in Portugal, for example, there is no regional authority with responsibilities on planning, but rather a national government that develops the entire spatial planning between the national and the city level. For this reason, there are no regional mitigation plans at NUTS 2 level. However, there is a more recent supra-municipal planning approach in Portugal acknowledging the importance of cooperation across "intermunicipal communities" (NUTS 3 level) also regarding climate action. The lack of structure is not only affecting regional planning but also local plans availability. For example, in Malta, existing CoM plans are implemented by different local councils which are part of the denominated European UA city (sampled in this study). The plans that do not cover the entire UA city have not been considered in this study, according to the data collection protocol designed in Reckien et al. (Reckien et al., 2019) and further improved in Salvia et al. (Salvia et al., 2021).

Overall, even in the absence of a timely and precise framework of national and regional coordination, European Mediterranean cities have advanced their climate planning and put in place coordinated actions to mitigate climate change. A clear pattern has been identified in relation to the size of the regions and the cities, having explicit climate action when the population is higher. However, further statistical work needs to support these findings as the sample is clearly dominated by big Western Mediterranean cities. This has been partly facilitated by the strong role of transnational climate networks such as the CoM in the Mediterranean area. On the other hand, this strong link to the CoM leads to a less ambitious, moderate situation in terms of mitigation targets (mostly up to $25 \%$ emission reduction). Most of them also refer to a rather short timeframe, i.e. the year 2020, which means that the existing SEAPs will need to be updated to (hopefully) more integrated and ambitious SECAPs in the coming years.

The submission of NECPs, the increased EU climate ambition (from $40 \%$ to $55 \%$ reduction of GHG) for the 2030 horizon announced by the European Commission in September (European Commission, 2020b), the necessity of the Member States to reinforce their efforts to meet the carbon neutrality proposed by the European Green Deal in 2050 in the framework of the European Climate Law (being developed), will potentially change the scene addressed by this study. In this renovated framework regions and cities' mitigation strategies will be crucial to accomplish Member States commitments, and presumable they will be further integrated in climate decision making at different levels in the years to come.

At this stage, no evidence of common policy approaches were found that could be seen as a common "Euro-Mediterranean mitigation strategy". The results suggest that most cities and regions have been following very closely the transnational CoM template. This leaves little room (probably also due to lack of capabilities and resources) to identify and include their specific needs and perspectives, some of which are expected to be shared across the European Mediterranean areas. This study revealed some patterns in mitigation planning in ME regions and cities: i) regional climate action is highly dependent on national regulation and requirements; ii) larger regions and cities have stronger climate action; iii) short-term ambition (in terms of GHG emission reduction targets) both in regions and cities is generally limited; iv) transnational networks, such as CoM and Under2MoU for cities and regions, play important roles in influencing climate actions. 


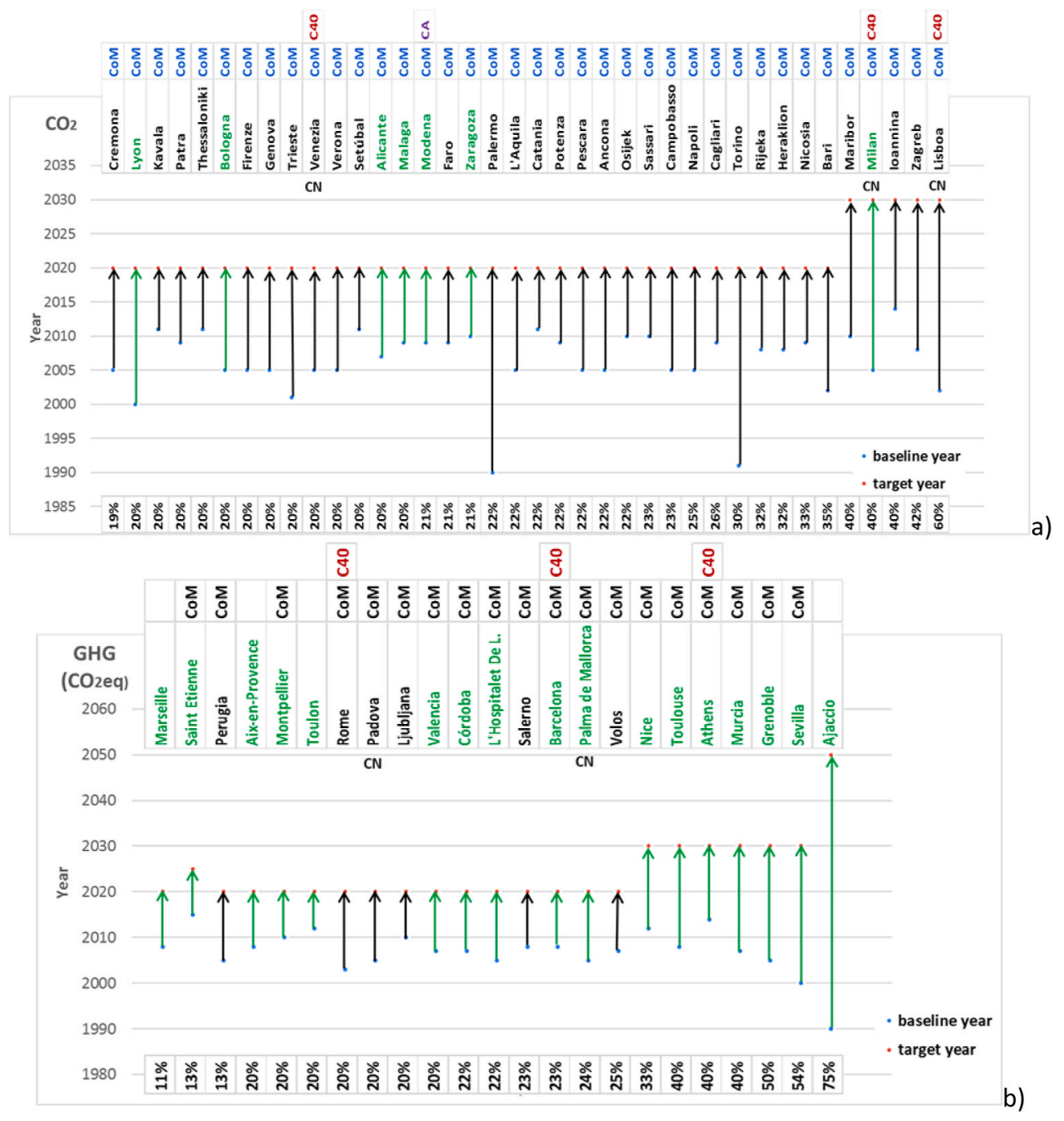

Fig. 6. Overview of mitigation targets in the analysed M-LCPs. Targets are expressed differently across cities in terms of $\mathrm{CO}_{2}$ (a) and $\mathrm{GHG} / \mathrm{CO}_{2 \text { eq }}$ (b). Cities highlighted in green located in regions with a M-RCP. "CN" indicates cities which strive for carbon neutrality on the long-term. Membership to transnational climate networks is also indicated (CoM - Covenant of Mayors, CA Climate Alliance, C40). (For interpretation of the references to colour in this figure legend, the reader is referred to the Web version of this article.)

a)

The results show that cities in the ME region do not develop plans with high ambitions, longer vision, develop autonomous plans, and do not integrate adaptation elements as much as the other European cities (Reckien et al., 2018). There is clearly a common need for ME cities to be supported by higher government levels (especially the regional one), further highlighting a political gap between regional action plans, local climate action and national structures. However, the observed uneven and fragmented panorama on regional and local mitigation planning found by this study does not seem to follow a "Mediterranean pattern", where progress with mitigation planning can be connected with the characteristics shared by these regions and cities in terms of environment, socio-political, climatic and economic conditions. This may be due to a lack of Mediterranean cross-national cooperation and policy coordination, which forces Mediterranean cities and regions to turn towards the guidance provided either by their respective national framework (when available) or towards the aforementioned transnational networks. The results support the call for a common Green Deal at the Mediterranean level to further address specific Mediterranean challenges and related needs and capitalise on available resources in order to build capacities and knowledge and help Mediterranean regions and cities to provide the next generation of mitigation plans. Such type of action will also deliver benefits at national level, especially for the Mediterranean countries for which there is no clear national regulation on regional/local mitigation planning. Currently there seems to be, for most of the studied countries, a policy gap which causes a lack of integration between regional action plans, local climate action plans and national climate mitigation strategies.

\section{Conclusions}

The aim of this study was to generate knowledge around mitigation strategies of cities and regions in the Euro-Mediterranean Area and to explore the case for a Mediterranean Green Deal based on environmental, socio-political and economic common characteristics and similar challenges that Mediterranean regions and cities face. The main patterns of regional and city level mitigation planning were investigated to identify convergences and divergences of their planning practice in order to understand the need and adequacy of a specific Mediterranean policy in this field. Particularly, the study focused on the availability of plans, their emission reduction targets and the impact of transnational climate networks within a representative sample of 51 regions and 73 cities across 9 Mediterranean countries.

Regional mitigation plans were found in $29.4 \%$ of the analysed Mediterranean regions, mainly in France and Spain. In Italy and Greece only $7.7 \%$ and $5.6 \%$ regions have a plan, respectively. Croatia, Portugal and Slovenia have no regional mitigation plans and NUTS 2 level regions correspond to the whole of Cyprus and Malta. At city-level, $83.6 \%$ of the studied cities (61 cities out of 73) have a mitigation plan and of these, $75.4 \%$ are mainly SEAP for 2020 developed in the framework of transnational networks as the CoM. Only 12 cities have longer term mitigation targets, mainly for the year of 2030. Mitigation targets are modest with only 5 cities aiming for carbon neutrality. Most local climate plans 
focus exclusively mitigation, although in 16 cities plans deal with both mitigation and adaptation. Moreover, only one third of the cities with a mitigation plan (M-LCP) belong to regions with a similar plan (M-RCP).

European regions and cities will be involved in different ways and levels in the months and years to come to align their climate policy to NECPs guidelines and ambition, which will require an update of this study. Further research should also include the analysis of the sectors, types and contents of specific mitigation policies and further correlation with environmental, socio-economic and economic parameters across Mediterranean regions and cities. Moreover, further investigation should also involve an analysis of adaptation plans, including those at other local (e.g. metropolitan) and regional (e.g. counties or provinces) scales, which could further test this hypothesis. As the Mediterranean is the most vulnerable geographical area in Europe, this work could provides evidence on regions and cities' ambitiousness and proposed actions, understanding the relationships between climate adaptation and mitigation planning as well as the territorial patterns in addressing climate change. Additionally, future data updates and corresponding research will allow to analyse the impact of the European Green Deal implementation on regional and city climate planning and related ambitions as well as the impact of new national legal developments, e.g. the upcoming Spanish Law for Climate and Energy Transition.

\section{Credit author statement}

Monica Salvia: Conceptualization, Data collection and curation, Investigation and Visualization, Writing - original draft, Writing - review \& editing, Marta Olazabal: Conceptualization, Data collection and curation, Investigation, Writing - original draft, Writing - review \& editing, Paris A. Fokaides: Conceptualization, Data collection and curation, Writing - original draft, Writing - review \& editing, Léa Tardieu: Data collection and curation, Investigation and Visualization, Writing - review \& editing, Sofia G. Simoes: Conceptualization, Data collection and curation, Investigation and Visualization, Writing original draft, Writing - review \& editing, Davide Geneletti: Data collection and curation, Writing - original draft, Writing - review \& editing, Sonia De Gregorio Hurtado: Data collection and curation, Writing - original draft, Writing - review \& editing, Vincent Viguié; : Conceptualization, Data collection and curation, Investigation and Visualization, Writing - review \& editing, Niki-Artemis Spyridaki: Data collection and curation, Writing - original draft, Writing - review \& editing, Filomena Pietrapertosa: Data collection and curation, Investigation and Visualization, Writing - review \& editing, Byron I. Ioannou: Data collection and curation, Writing - original draft, Writing - review \& editing, Marko Matosović: Data collection and curation, Investigation and Visualization, Writing - original draft, Alexandros Flamos: Conceptualization, Data collection and curation, Writing - review \& editing, Mario V. Balzan: Data collection and curation, Writing - review \& editing, Efren Feliu: Data collection and curation, Writing - review \& editing, Klavdija Rižnar: Data collection and curation, Nataša Belšak Šel: Data collection and curation, Oliver Heidrich: Conceptualization, Writing - review \& editing, Diana Reckien: Supervision, Writing - review \& editing.

\section{Declaration of competing interest}

The authors declare that they have no known competing financial interests or personal relationships that could have appeared to influence the work reported in this paper.

\section{Acknowledgements}

This study was carried out by a subset of the members of the EUROLCP Initiative, a group of scientists across the 28 (previous) member states of the European Union regularly analysing a representative sample of local, regional, and national climate change plans and policies in these countries. The initiative was originally established by the core research network of the EU COST Action TU0902 (2009-2014). MO's research is funded by the Spanish State Research Agency through María de Maeztu Excellence Unit accreditation 2018-2022 (Ref. MDM-20170714) and by the Basque Government BERC 2018-2021 program. DG is supported by the Italian Ministry of Education, University and Research (MIUR) in the frame of the "Departments of Excellence" grant L. 232/ 2016.

\section{Appendix A. Supplementary data}

Supplementary data to this article can be found online at https://doi. org/10.1016/j.jenvman.2021.113146.

\section{References}

Apanaviciene, R., Vanagas, A., Fokaides, P.A., 2020. Smart building integration into a smart city (SBISC): development of a new evaluation framework. Energies 13. https://doi.org/10.3390/en13092190.

ARLEM, 2020. Euro-Mediterranean Regional and Local Assembly.

Babou, W., Grunewald, N., Ouellet-Plamondon, C., Gressot, M., Galli, A., 2017. The Ecological Footprint of Mediterranean cities: awareness creation and policy implications. Environ. Sci. Pol. 69 https://doi.org/10.1016/j.envsci.2016.12.013.

Billé, R., Downing, T., Garnaud, B., Magnan, A., Smith, B., Taylor, R., 2013. Adaptation strategies for the Mediterranean. In: Advances in Global Change Research. Springer International Publishing, pp. 235-262. https://doi.org/10.1007/978-94-007-5772112 .

C40 cities, 2018. C40 Cities [WWW Document].

Climate Alliance, 2020. Climate Alliance [WWW Document].

Cohesify, 2017. A Regional Development without Regions? [WWW Document].

Cramer, W., Guiot, J., Fader, M., Garrabou, J., Gattuso, J.P., Iglesias, A., Lange, M.A., Lionello, P., Llasat, M.C., Paz, S., Peñuelas, J., Snoussi, M., Toreti, A., Tsimplis, M.N., Xoplaki, E., 2018. Climate change and interconnected risks to sustainable development in the Mediterranean. Nat. Clim. Change 8, 972-980. https://doi.org/ 10.1038/s41558-018-0299-2.

Cramer, W., Guiot, J., Marini, K., 2020. Climate and Environmental Change in the Mediterranean Basin Current Situation and Risks for the Future 1st Mediterranean Assessment Report. Marseille.

De Gregorio Hurtado, S., 2020. A Green Deal for the Urban Age: a new role for cities in EU climate action. In: Abdullah, H. (Ed.), The Urban Dimension of the European Green Deal. CIDOB, Barcelona.

De Gregorio Hurtado, S., Olazabal, M., Salvia, M., Pietrapertosa, F., Olazabal, E., Geneletti, D., D’Alonzo, V., Feliú, E., Di Leo, S., Reckien, D., 2014. Implications of governance structures on urban climate action: evidence from Italy and Spain. In: Working Papers 2014-02, BC3., Working Papers 2014-02, BC3.

Dhakal, K.P., Chevalier, L.R., 2017. Managing urban stormwater for urban sustainability: barriers and policy solutions for green infrastructure application. J. Environ. Manag. 203 https://doi.org/10.1016/j.jenvman.2017.07.065.

EU Covenant of Mayors, 2020. Covenant of Mayors for Climate and Energy - Europe [WWW Document].

European Commission, 2019. COM(2019) 640 Final. Green New Deal. Communication from the Commission to the European Parliament. the European Council, the Council, the European Economic and Social Committee and the Committee of the Regions.

European Commission, 2020a. National Energy and Climate Plans (NECPs) [WWW Document].

European Commission, 2020b. COM(2020) 562 Final. Stepping up Europe's 2030 Climate Ambition Investing in a Climate-Neutral Future for the Benefit of Our People.

European Committee of the Regions, 2020. Climate Emergency: Local and Regional Leaders Call for a Green Deal for the Mediterranean ([WWW Document]).

European Parliament and of the Council, 2013. Commission Regulation (EU) No 1319/ 2013 Amending Annexes to Regulation (EC) of the European Parliament and of the Council on the Establishment of a Common Classification of Territorial Units for Statistics (NUTS).

Eurostat, 2020a. City Statistics Database ([WWW Document]).

Eurostat, 2020b. Population on 1 January by NUTS 2 Region ([WWW Document]).

FAO, 2018. State of Mediterranean Forests 2018. Food and Agriculture Organization of the United NationsandPlan Bleu. Regional Activity Center of UN Environment/ Mediterranean Action Plan, Rome.

Giorgi, F., Lionello, P., 2008. Climate change projections for the Mediterranean region. Global Planet. Change 63, 90-104. https://doi.org/10.1016/j. gloplacha.2007.09.005.

Heidrich, O., Reckien, D., Olazabal, M., Foley, A., Salvia, M., de Gregorio Hurtado, S., Orru, H., Flacke, J., Geneletti, D., Pietrapertosa, F., Hamann, J.J.-P., Tiwary, A., Feliu, E., Dawson, R.J., 2016. National climate policies across Europe and their impacts on cities strategies. J. Environ. Manag. 168 https://doi.org/10.1016/j. jenvman.2015.11.043.

Iglesias, A., Garrote, L., Flores, F., Moneo, M., 2007. Challenges to manage the risk of water scarcity and climate change in the Mediterranean. Water Resour. Manag. 21, 775-788. https://doi.org/10.1007/s11269-006-9111-6. 
Interreg Med Programme, 2020. Interreg MED [WWW Document].

Karhinen, S., Peltomaa, J., Riekkinen, V., Saikku, L., 2021. Impact of a climate network: the role of intermediaries in local level climate action. Global Environ. Change 67. https://doi.org/10.1016/j.gloenvcha.2021.102225.

Lelieveld, J., Hadjinicolaou, P., Kostopoulou, E., Chenoweth, J., El Maayar, M., Giannakopoulos, C., Hannides, C., Lange, M.A., Tanarhte, M., Tyrlis, E., Xoplaki, E., 2012. Climate change and impacts in the eastern Mediterranean and the Middle East. Climatic Change 114, 667-687. https://doi.org/10.1007/s10584-012-0418-4.

Linares, C., Díaz, J., Negev, M., Martínez, G.S., Debono, R., Paz, S., 2020. Impacts of climate change on the public health of the Mediterranean Basin population - current situation, projections, preparedness and adaptation. Environ. Res. $182 \mathrm{https}$ ///doi. org/10.1016/j.envres.2019.109107.

Loizidou, M., Giannakopoulos, C., Bindi, M., Moustakas, K., 2016. Climate change impacts and adaptation options in the Mediterranean basin. Reg. Environ. Change 16, 1859-1861. https://doi.org/10.1007/s10113-016-1037-9.

Ministry of Economic Development, 2019. Ministry of the Environment and the Protection of the Territory and the Sea, Ministry of Infrastructure and Transport. Piano Nazionale Integrato per l'Energia e il Clima (National Energy and Climate Plan).

Ministry of Regional Development and EU Funds, 2020. Presentation of the Study on the Proposal for a New NUTS 2 Classification (Predstavljena Studija O Izradi Prijedloga Nove NUTS 2 Klasifikacije ([WWW Document]).

Nicholls, R.J., Hoozemans, F.M.J., 1996. The Mediterranean: vulnerability to coastal implications of climate change. Ocean Coast. Manag. 31, 105-132. https://doi.org/ 10.1016/S0964-5691(96)00037-3.

Olazabal, M., De Gregorio, S., Olazabal, E., Pietrapertosa, F., Salvia, M., Geneletti, D., D'Alonzo, V., Feliú, E., Leo di, S., Reckien, D., 2014. How are Italian and Spanish Cities tackling climate change? A local comparative study. BC3 Work. Pap. Ser. Basqu. Cent. Clim. Chang. BC3.

Palumbo, R., Manesh, M.F., Pellegrini, M.M., Caputo, A., Flamini, G., 2021. Organizing a sustainable smart urban ecosystem: perspectives and insights from a bibliometric analysis and literature review. J. Clean. Prod. 297 https://doi.org/10.1016/j. jclepro.2021.126622.

Pietrapertosa, F., Salvia, M., De Gregorio Hurtado, S., Geneletti, D., D’Alonzo, V., Reckien, D., 2021. Multi-level climate change planning: an analysis of the Italian case. J. Environ. Manag. 289 https://doi.org/10.1016/j.jenvman.2021.112469.

Pisoni, E., Christidis, P., Thunis, P., Trombetti, M., 2019. Evaluating the impact of "Sustainable Urban Mobility Plans" on urban background air quality. J. Environ. Manag. 231 https://doi.org/10.1016/j.jenvman.2018.10.039.

Polydoros, A., Mavrakou, T., Cartalis, C., 2018. Quantifying the trends in land surface temperature and surface urban heat island intensity in Mediterranean cities in view of smart urbanization. Urban Sci. 2, 16. https://doi.org/10.3390/urbansci2010016.

Reckien, D., Flacke, J., Dawson, R.J., Heidrich, O., Olazabal, M., Foley, A., Hamann, J.J.P., Orru, H., Salvia, M., De Gregorio Hurtado, S., Geneletti, D., Pietrapertosa, F., 2014. Climate change response in Europe: what's the reality? Analysis of adaptation and mitigation plans from 200 urban areas in 11 countries. Climatic Change 122, 331-340. https://doi.org/10.1007/s10584-013-0989-8.

Reckien, D., Flacke, J., Olazabal, M., Heidrich, O., 2015. The influence of drivers and barriers on urban adaptation and mitigation plans-an empirical analysis of European Cities. PloS One. https://doi.org/10.1371/journal.pone.0135597.

Reckien, D., Salvia, M., Heidrich, O., Church, J.M., Pietrapertosa, F., De GregorioHurtado, S., D’Alonzo, V., Foley, A., Simoes, S.G., Krkoška Lorencová, E., Orru, H., Orru, K., Wejs, A., Flacke, J., Olazabal, M., Geneletti, D., Feliu, E., Vasilie, S., Nador, C., Krook-Riekkola, A., Matosović, M., Fokaides, P.A., Ioannou, B.I., Flamos, A., Spyridaki, N.A., Balzan, M.V., Fülöp, O., Paspaldzhiev, I., Grafakos, S., Dawson, R., 2018. How are cities planning to respond to climate change? Assessment of local climate plans from 885 cities in the EU-28. J. Clean. Prod. 191, 207-219. https://doi.org/10.1016/j.jclepro.2018.03.220.
Reckien, D., Salvia, M., Pietrapertosa, F., Simoes, S.G., Olazabal, M., De Gregorio Hurtado, S., Geneletti, D., Krkoška Lorencová, E., D’Alonzo, V., Krook-Riekkola, A., Fokaides, P.A., Ioannou, B.I., Foley, A., Orru, H., Orru, K., Wejs, A., Flacke, J., Church, J.M., Feliu, E., Vasilie, S., Nador, C., Matosović, M., Flamos, A., Spyridaki, N.-A., Balzan, M.V., Fülöp, O., Grafakos, S., Paspaldzhiev, I., Heidrich, O., 2019. Dedicated versus mainstreaming approaches in local climate plans in Europe. Renew. Sustain. Energy Rev. 112 https://doi.org/10.1016/j.rser.2019.05.014.

Regions4, 2020. Global Network for Climate Change. Biodiversity \& SDG ([WWW Document]).

Ribas, A., Olcina, J., Sauri, D., 2020. More exposed but also more vulnerable? Climate change, high intensity precipitation events and flooding in Mediterranean Spain. Disaster Prev. Manag. An Int. J. 29, 229-248. https://doi.org/10.1108/DPM-052019-0149.

Ruiz, I., Almagro, M., García de Jalón, S., Solà, M.del M., Sanz, M.J., 2020. Assessment of sustainable land management practices in Mediterranean rural regions. J. Environ. Manag. 276 https://doi.org/10.1016/j.jenvman.2020.111293.

Salvia, M., Reckien, D., Pietrapertosa, F., Eckersley, P., Spyridaki, N.-A., KrookRiekkola, A., Olazabal, M., De Gregorio Hurtado, S., Simoes, S.G., Geneletti, D., Viguie, V., Fokaides, P., Ioannou, B.I., Flamos, A., Szalmane Csete, M., Buzási, A., Orru, H., de Boer, C., Foley, A.M., Riznar, K., Matosovic, M., Balzan, M., Smigaj, M., Bastakova, V., Streberova, E., Belšak Šel, N., Coste, L., Tardieu, L., Altenburg, C., Krkoska Lorencova, E., Orru, K., Wejs, A., Feliu, E., Church, J.M., Grafakos, S., Vasilie, S., Paspaldzhiev, I., Heidrich, O., 2020. Will Climate Mitigation Ambitions Lead to Carbon Neutrality? an Analysis of the Local-Level Plans of 327 Cities in the EU: Datasets and Supplementary Materials. https://doi.org/10.17632/8CK GB2TV8G.1.

Salvia, M., Reckien, D., Pietrapertosa, F., Eckersley, P., Spyridaki, N.A., KrookRiekkola, A., Olazabal, M., De Gregorio Hurtado, S., Simoes, S.G., Geneletti, D., Viguié, V., Fokaides, P.A., Ioannou, B.I., Flamos, A., Csete, M.S., Buzasi, A., Orru, H., de Boer, C., Foley, A., Rižnar, K., Matosović, M., Balzan, M.V., Smigaj, M., Baštáková, V., Streberova, E., Šel, N.B., Coste, L., Tardieu, L., Altenburg, C., Lorencová, E.K., Orru, K., Wejs, A., Feliu, E., Church, J.M., Grafakos, S., Vasilie, S., Paspaldzhiev, I., Heidrich, O., 2021. Will climate mitigation ambitions lead to carbon neutrality? An analysis of the local-level plans of 327 cities in the EU. Renew. Sustain. Energy Rev. 135, 110253 https://doi.org/10.1016/j.rser.2020.110253.

Schneider, S.M., Sanguinetti, A., 2021. Positive reinforcement is just the beginning: associative learning principles for energy efficiency and climate sustainability. Energy Res. Soc. Sci. 74 https://doi.org/10.1016/j.erss.2021.101958.

The Climate Group, 2020. How States and Regions Are Preparing for the Climate Decade 2020 ([WWW Document]).

Tiwary, A., Williams, I.D., Heidrich, O., Namdeo, A., Bandaru, V., Calfapietra, C., 2016. Development of multi-functional streetscape green infrastructure using a performance index approach. Environ. Pollut. 208 https://doi.org/10.1016/j. envpol.2015.09.003.

Under2 Coalition, 2020. Under2 Coalition [WWW Document].

UNEP/MAP, 2016. Mediterranean Strategy for Sustainable Development 2016-2025. Investing in Environmental Sustainability to Achieve Social and Economic Development. United Nations Environment Programme/Mediterranean Action Plan, Valbonne, France.

United Nations Climate Change, 2020. Data Partnerships for the Non-state Actor Zone for Climate Action (NAZCA). UNFCCC [WWW Document].

Vinet, Bigot, Petrucci, Papagiannaki, Llasat, Kotroni, Boissier, Aceto, Grimalt, LlasatBotija, Pasqua, Rossello, Kılıç, Kahraman Tramblay, 2019. Mapping flood-related Mortality in the Mediterranean basin. Results from the MEFF v2.0 DB. Water 11, 2196. https://doi.org/10.3390/w11102196.

Wang, S., Gao, S., Li, S., Feng, K., 2020. Strategizing the relation between urbanization and air pollution: empirical evidence from global countries. J. Clean. Prod. 243 https://doi.org/10.1016/j.jclepro.2019.118615. 